Милица Јотов

jotov@t-com.me

https://doi.org/10.18485/ai_diskurs_pobede.2019.ch13

821.163.41.09-13 Петровић Његош П. II

821.163.41:929 Петровић Његош П. II

\title{
ДИСКУРС ПОБЕДЕ У ЊЕГОШЕВОМ ГОРСКОМ ВИЈЕНЦУ
}

Инспирацију за писање овог рада ауторка налази у сећању на проф. Танаку Казуа и дане када је сведочила превођењу Његошевог капиталног дела Горски вијенаи, на јапански језик.

Разумевање културолошко-историјског контекста, уочавање сличности националног карактера Јапана и Црне Горе, поређење филозофско-ратничких концепата бушидо кодекса и чојства и јунаштва само су неке од бројних препрека које је требало савладати у јуначком преводилачком подухвату професора Танаке.

Кључне речи: Његош, Горски вијенаи, јапански језик, Казуа Танака.

\section{1. Појам победе}

Концепт победе и тумачење овог термина далеко је комплекснији задатак од налажења преводног еквивалента за који постоји апсолутно адекватна реч у оба језика, како у директном (直訳) тако и у смисленом（意訳） преводу. Победа = 勝, јесте реч која означава тријумф, имплицира борбу, такмичење, рат... и означава појам супротан од пораза. Победа\#пораз су са лингвистичког аспекта апсолутно супротстављени појмови који озна- 
чавају два различита исхода истог догађаја са снажном позитивно/негативном конотацијом и резервисани су за припаднике зараћених табора (победнички и поражени). Посебан израз Пирова победа резервисан је за победу извојевану уз велике жртве, те се изједначава са поразом. Осим Пирове, свака друга врста победе означава тријумф над пораженим. У том смислу, није могуће делимичан успех описати као малу победу, док потпуни успех често називамо великом победом. Такође, ретко или никад кажемо мали пораз, а често велики пораз. Све горе наведено указује на непомирљивост значења појмова победа и пораз како у форми тако и у садржају.

У филозофском смислу, будистичко-конфучијанском као и у хришћанско-религијском, победа не мора нужно означавати добитак, нити пак пораз мора означавати губитак. Самурајски кодекс части веома је сличан концепту чојства и јунаштва који чини потку црногорског културолошког миљеа. Образ и част су важнији од саме победе или пораза. Ратник самурај (武士) оличење је врлина и лучоноша поштења, оданости и храбрости баш као и Његошев јунак коме је „образ“ важнији од било каквог материјалног добитка. Победа је циљ, нада, жеља сваког ратника, али само уколико је часна, достојна имена које ратник носи. Победа се мери главама непријатеља, на једном тасу на ваги правде Вечног суда који се зове морал и мир у души, и чашћу и образом ратника који се могу зарадити или ненадокнадиво изгубити, на другом. У хришћанско-религијском смислу, обећана награда за исправно понашање јесте рај на небу, обећан загробни живот који почиње тек када се овај земаљски, пролазни заврши. Одрицање, патња и скромност воде ка исправном хришћанском животу који је сигурна стаза на путу до обећаног раја. Један од постулата хришћанства налаже - Не убиј ближњега свога. Служба ратника подразумева одузимање душманских живота, што не- 
миновно води до закључка да ратник не може заслужити рај. Свештеници дају опрост ратницима помиловавши их речима - није грех од греха се силом борити. Како Петар Петровић Његош каже:

Вук на овцу своје право има

ка тирјанин на слаба човјека; ал' тирјанству стати ногом за врат, довести га к познанију права, то је људска дужност најсветија!

Хришћански ратови су се водили за славу и у славу јединог бога. Победа над неверницима је победа хришћанства над безбожницима. У Његошевом Горском вијениу концепт борбе и победе синоним је за борбу хришћанства против ислама и победу домаћих против „дођоша“. У рату и љубави је све дозвољено, али се част и образ не смеју довести у питање. Његошеви јунаци поштују непријатеља, уважавају га указујући му част, чак, парадоксално, и гостопримство. На овај начин Црногорци подвлаче, већ пословичну, домаћинску врлину. Они Турке уважавају чак и описујући их: „...силан Турчин коња јаше.... . Победа над Турчином није само узимање главе, то је победа јединог бога Исуса Христа над Алахом, победа праве вере над незнабожачком. Оно што је јапанском читаоцу тешко да схвати јесте вишевековна борба религија које само у малом проценту постоје у Јапану, али и вишевековна нетрпељивост народа, турског и српског, који су пола миленијума делили судбину. Више од 8.000 речи, од којих је више од 3.000 у свакодневној употреби у савременом српском језику, ритуали (посебно испијања кафе уз ратлук), готово идентична кухиња, манири, обичаји, ношња и навике, сведоче о интеркултуралној размени 
и мешању народа, језика и традиције. Јапан је земља географски и културолошки веома удаљена и од Србије и Црне Горе и од Турске. За „свет који испија чај“ ( お茶 を飲む世界), било је веома тешко да схвати „свет који испија кафу“ (コーヒーを飲む世界). Такође, јапанском читаоцу није било лако да схвати тежњу за религијском моћи, јер мултирелигијска сцена Јапана толерише постојање свих верских опредељења и чак усваја елементе истих (прослава Божића, Ускрса, Св. Патрика, Ускрса...). Такође, у архитектури се огледа толеранција према другим религијама и културама (постојање цркава, џамија, храмова). Још теже, како су јапански преводиоци навели, било је заинтересовати јапанског читаоца за историју Балкана. Оригинални десетерац претворен је у четрнаестерац, а језик Његоша преведен на архаични јапански језик који је доста тежак и неразумљив млађој популацији. Оно што је заједничка полазна тачка за тумачење и разумевање, јесте концепт чојства и јунаштва и самурајског кодекса части у контексту победе. Филозофски приступ концепту победе наглашава и победу морала ратника чак у вихору рата. Ратник част ставља испред мржње према непријатељу. Наиме, још један постулат хришћанске религије - Не убиј ближњега свога! Одузимање живота је неопростив грех, а одузимање свог живота још већи. Јапанском читаоцу није лако да схвати овај хришћански закон, јер је Харакири или Сепуку ритуално самоубиство (腹切、切腹) велика част и привилегија чувених ратника, која је уједно и победа над самим собом, потврда части, храбрости и оданости. Постоје две врсте харакирија. Једна је харакири који самурај врши добровољно: да не би пао у руке непријатеља који га је опколио или сустигао након пораза војске у којој се борио; или сустигао са намером да га зароби; да покаже верност умрлом или погинулом господару (често на његовом гробу); да изрази 
протест због понашања феудалног господара или било кога који је по рангу виши од њега и коме, према важећим друштвеним правилима, не може да се отворено супротстави, итд. Друга врста харакирија је она коју самурај врши по наређењу претпостављеног, због неке учињене грешке или по одлуци суда, што уједно представља и опрост, јер само је цењеном ратнику дозвољено да на овај начин поврати укаљану или изгубљену част. Самоубиство у хришћанском свету не само да је непожељан, већ је и неопростив чин. Док у јапанској култури овај свечани ритуал, који се често изводи уз највеће војне почасти, испод процвалог дрвета трешњиног цвета који је симбол пролазности живота, уз хаику посмртни стих ратника песника, чајну церемонију, представља врхунац победе лепоте над пролазношћу, храбрости над страхом, морала над нечашћу, у нашој култури он означава пораз, кукавичлук и бежање. Превести Горски вијенаи на јапански језик био је лакши задатак од приближавања српске културе јапанском читаоцу. Историја Балкана се веома мало или готово нимало проучава у јапанским школама. И сам подухват професора Танаке представља победу и савладавање непрегледног географског, културолошког и језичког јаза. Вук Мандушић је алфа мужјак, рођени лидер, неустрашиви јунак, вешт са оружјем, срчан и јак, умногоме подсећа на јапанског ратника аристократу, часног самураја. Он је одан свом господару, истрајан у борби против потурица, неумољив и снажан. Има све особине јапанског самураја, те читаоцима у Јапану врло брзо постаје омиљени јунак.

\section{2. Хуманизам у самурајском кодексу части}

Културолошка специфичност ренесансе и хуманизма у Јапану кроз веома дугу историју досеже до Кон- 
фучија и Буде истичући људско достојанство и хумане међуљудске односе на примеру самурајског кодекса части, још много пре Сократа који се сматра првим великим светским хуманистом. О хуманизму се у Европи говори од времена Старих Грка, док се у Азији помиње у старим списима још пре 2 до 3 хиљаде година. Хуманизам васкрсава у доба ренесансе и остаје снажна филозофска сила до данашњих дана.

Први хришћански Језуити који су стигли у Јапан мислили су да су нашли азијски пандан свом хришћанском хуманизму, међутим ваља истаћи да је хришћански хуманизам теоцентричан док су и будизам и конфучијанизам у хуманистичком погледу довољно јаки да ниједан од њих не захтева божанску помоћ за постизање ослобођења, просветљења или доброг живота.

Хуманизам на Путу ратника - бушидо у Јапану најбоље се може описати конфучијанском пословицом: „Људи су ти који Пут чине великим, није Пут тај који људе чини великим“. Самураји инспирацију и ослонац налазе у Зен будизму који слави лепоту пролазности и пролазност лепоте враћајући се традицији кроз ритуале попут чајне церемоније, калиграфије или церемоније мириса. Седам врлина чине основу неписаног кодекса који се односи на морална начела ратника.

Ги(義): искреност, праведност

Jу (勇): храброст

Ђин (仁): доброта

Pеј(礼): учтивост, уљудност

Макото (誠) или Шин (真): истина, честитост

Меијо (名誉): част

Ћуги (忠義): верност или Ћу (忠): дужност и лојалност

Повреда и кршење ових моралних начела може се искупити само ритуалним залогом сопственог живота (сепуку), који трајно скида срамоту са имена самураја 
и његовог потомства.

Чувени самурај Мијамото Мусаши, велики мачевалац, био је и изванредан вајар, калиграф и сликар. Истински самурај је морао бити свестран, а осим ратничке настојао је изразити и своју уметничку особеност. Такође, морао је стећи високо образовање у пољу хуманистичких наука, док је изучавање математике било запостављено (цењене су духовне, а не материјалне вредности).

У доба ренесансе која је у Јапану отпочела у 18. веку, људи се враћају традиционалним вредностима утемељеним у ратничком моралном кодексу, филозофији и образовању који су поред катане најмоћније оружје самураја у борби против сопственог ега и највећа потпора емпатији и поштовању према рањеном противнику. Отвара се богата ризница јапанске културе, оживљавају се стари обичаји, церемоније, уметност и књижевност, а древна јапанска поезија и историја се откривају у својој раскошној лепоти у праскозорје ренесансе попут трешњиног дрвета у пуном цвату.

3. Чојство и јунаштво црногорских јунака

Чојство и јунаштво осим Његоша најлепше описује Марко Миљанов који је ове две особине вредновао као најцењеније људске врлине. Јунаштво је врлина којом себе бранимо од зла других, док је чојство врлина којом друге бранимо од зла у себи, с тим што је чојство испред јунаштва. Ово је, као и бушидо, неписани кодекс части, не само ратничке класе већ и целог црногорског друштва. Образ, част, поштење вреде више од овоземаљског живота, а својим делима човек се може попети до небеских висина, а часно име вечно сачувано у сећању будућих покољења. Као што рече Марко Миљанов, перјаник кнеза Црне Горе Данила Петровића: 
Јунаштво је кад себе браним од другога, чојство је кад другога браним од себе.

На Википедији налазимо тумачење овог концепта на следећи начин:

„Риједак је у свијету народ, у свим временима, који свој квалитет одређује моралним разлозима. 'Народ замишљен над својим карактером', какви су Црногорци-Срби, непознат је свјетској историји. Један од барјактара овога народа, народа код кога је мисао правде већ у дјетињству заметнута, или је још старија и од предака, дубоко замишљен собом, истражује сопствену моћ, правичност и правду. Миљанов каже да је највеће јунаштво чојство, и да је то она побједа када од себе сачуваш друге.“

Напротив, готово идентичан концепт налазимо у јапанском друштву у самурајском кодексу части утемељеном на конфучијанским моралним начелима.

Чињеница да су се на веома географски, културолошки и језички удаљеним земљама као што су Јапан и Црна Гора развили готово истоветни неписани морални закони, ово истраживање чини још интересантнијим и сложенијим и отвара нова поља на шареноликој цивилизацијској мапи.

\section{4. Закључак}

Ауторка овог рада имала је за циљ да истражи лингвистичко-књижевни и религијско-филозофски дискурс победе у Његошевом Горском вијениу и објасни како је ово значајно дело изазвало огромно интересовање у Јапану, земљи која је географски и културолошки веома удаљена од нас. Неминовно, ова компаративна анализа је продрла и у друге слојеве јапанске и српско-црногорске културе и отворила многа питања 
на која ћемо дати одговоре у неким будућим радовима.

Појам победе код Његоша јесте синоним за појам слободе. Ослободити се турског зулума и јарма значи извојевати победу како у политичком, тако и у религиозно-филозофском контексту. Ригидан концепт хришћанског дуализма добра и зла, награде и казне, свеприсутан у Горском вијениу, супротстављен је толерантнијој будистичкој филозофској мисли и концепту јина и јанга. У сваком злу постоји зрно добра, у сваком добру зрно зла. Аналогно, у свакој победи се налази део пораза, и обратно.

Ауторка је имала част и задовољство да учи од свог ментора проф. Казуо Танаке баш у време када је професор превео Горски вијенаи (након што је превео дела Иве Андрића) на јапански језик. Лингвистичка формула за превод је, по проф. Танаки аналогна математичкој и решава се попут једначине. Књижевни дискурс је тежи за анализу, јер се без познавања друштвено-историјског контекста не може разумети сложена проблематика српске религијске сцене. Тако појам победе није довољно превести јапанским апсолутним преводним еквивалентом 勝ち (каћи), већ је неопходно читаоцу из сасвим различитог културолошког миљеа приближити и појаснити прилике у „земљи сељака на брдовитом Балкану“. Јапанском читаоцу је јасно да победа значи исход борбе два ратника, два самураја, али му без додатних објашњења вештог преводиоца победа српства и хришћанства у земљи пуној потурица остаје неразумљив појам.

Ако дух професора Танаке плови Дрином и Дунавом посутим његовим пепелом, како верују његови сународници, онда ће овај мали научни допринос бољем разумевању двеју удаљених култура бити мост пријатељства између Србије и Јапана - На Дрини ћуприја. 


\section{Извори и литература}

Банашевић, Никола. „Поезија младога Његоша“. Савременик 9 (1955): 237-249.

Дворниковић В. Каракӣеролоїија Јуїословена. Београд: Космос, 1990.

Деретић, Јован. Крайка исӣорија сриске књижевностии VI Предроманиичзам.

Енииклойеgија тексикоїрафскої завоgа. Загреб: Југословенски лексикографски завод, 1962.

Калезић, Димитрије. Ейика Горскої вијениа. Београд, 1987.

Карановић М. Избор мисли. Ријека: Отокар Кершовани, 1979. Мала енциклойеgија Просветиа. Београд: Просвета, 1959.

Поповић, Павле. О Горском вијениу. Београд, 1923.

Секулић, Исидора. Њеі̄ошу кюиі̄а gубоке оgаностии, I. Београд, 1951.

\section{Milica Jotov}

\section{THE DISCOURSE OF VICTORY IN NJEGOŠ’S} THE MOUNTAIN WREATH

The inspiration for writing this work is found in the memory of Professor Tanaka Kazua and the days when she witnessed the translation of Njegošs capital work The Mountain Wreath into Japanese.

Understanding the cultural-historical context, recognizing the similarity of the national character of Japan and Montenegro, comparing the philosophical and warlike concepts of the Bushido codex and chastity and heroism are just a few of the obstacles to be overcome in Professor Tanaka's heroic translation endeavor.

Key words: Njegoš, The Mountain Wreath, the Japanese Language, Kazua Tanaka. 